Ophthalmologica 1979;179:I-V

\title{
Contents, Vol. 179, 1979
}

Contents Vol. 179, 1979

No. 1

Editorial 1

Report

Jones, B. R.: Report to the InternationalCouncil of Ophthalmology Concerning theInternational Agency for the Prevention ofBlindness

4

Original Paper

Pau, H.: Metastatische Aderhauttumoren vorund nach Röntgenbestrahlung 7

Loffredo, A.; Cennamo, G.; Sammartino, A., and Crecchio, G. de: The Value of theAssociation of Radiological Methods withEchographic Examination in the Study ofIntraocular Foreign

Bodies 18

Larmande, A. et Rossazza, C: Métastases or-bitaires enophtalmiantes 25

Francois, J. et Rijsselaere, M.: Keratomycoses 32

Litricin, O.: Endogenous Fungus Endophthal-mitis (Probably Aspergillus) 42

Pinckers, A. J. L.: Leber's Congenital Amau-rosis as Conceived by Leber 48

Danopoulos, E. D. and Danopoulou, I. E.:Effects of Urea Treatment in Combinationwith

Curettage in Extensive PeriophthalmicMalignancies 52

Mester, U.: Tierexperimentelle Ergebnisse mitHydrogel-Keratoprothesen unterschiedli-chen

Wassergehaltes 62

Letter to the Editor

Erkkilä, H.; Tarkkanen, A.; Haltia, M.; Pateau, A.; Kaakinen, K.; Vaheri, A.; Donner, M., and

Holmström, T.: FluoroangiographicPicture of the Acute Stage in Measles Ret-inopathy 70

Book Reviews 71

Announcement $\quad 72$

No. 2

Original Paper

Haneveld, G. T. and Hamburg, A.: Sweat GlandTumour of the Eyelid with

ConjunctivalInvolvement 73

Tarkkanen, A.; Laatikainen, L.; Mäkinen, J., and Merenmies, L.: Mediastinal

EmbryonalCarcinoma with Bilateral Choroidal Métastases. Fluorescein Angiography and Histopathologic Study 77

Sammartino, A.; Bonavolontà, G.; Pettinato, G., and Loffredo, A.: Exophthalmos Causedby an Invasive Pituitary Adenoma in aChild 83

Godel, V.; Nemet, P., and Lazar, M.: Congenital Ocular Motor Apraxia - FamilialOccurrence 90

Hatt, M. und Anderson, R. L.: Ptosischirurgie:Verkürzung der Levator-Aponeurose vonvorn 94

Kottow, M. H.: Trabeculectomy with ScleralWick. Technique and Early Results 99 
Chioralia, G.; Salminen, L.; Baurmann, H.und Dragomirescu, V.: Permeabilitätsunter-schiede neugebildeter Hornhautgefässe fürFITC-Dextrane 104

Francois, J. and Verbraeken, H.: Relationshipbetween the Drainage of the SubretinalFluid in Retinal Detachment Surgery andthe Appearance of Macular Pucker Ill

Öhrström, A. and Pandolfi, M.: Hypotensive Synergism of Propranolol and Adrenalin 115

Arciniegas, A. and Amaya, L. E.: Interaction between Anterior and Vitreous Chambers 119

Clinicopathologic Case Report

Daicker, B. C: Multiple Myxome der Lider . . 125

No. 3 Original Paper

Francois, J.: Neonatal or Juvenile Leucocoria 129

Cardillo Piccolino, F.; Zingirian, M., and Pa-rodi, G. C: Electronic Image Analysis inRetinal

Fluoroangiography (with 1 ColourPlate) 142

Amemiya, T.; Yoshida, H.; Harayama, K., andYokoo, N.: Massive Periretinal Proliferation in

Retinal Detachment in Relation toDiabetes mellitus 148

Francois, J.; Verbraeken, H., and Hanssens, M.: Scleral Pockets and Lyophilized Sclerain Retinal Detachments 153

IV

Contents

Stefani, F. H. und Alexandridis, A. K.: Gefäss-veränderungen im proximalen Fasciculusopticus beim kindlichen Glaukom 158

Greco, A. V.; Ricci, B.; Altomonte, L.; Re-buzzi, A. G.; Manna, R., and Ghirlanda, G.: GH

Secretion in Open-Angle Glaucoma 168

Gutierrez Diaz, A.; Jimenez Carmena, J.;Ruano Martin, F.; Diaz Lopez, P., andMuñoz Casado, M. J.: Intraocular Hemorrhage in Sudden Increased intracranialPressure (Terson Syndrome) 173

Clinicopathological Case Reports

Haddad, R.; Witzmann, K., and Braun, O.:Metastatic Calcification to the PeripheralFundus in

Chronic Renal Failure 178

Book Reviews $\quad 184$

Announcements $\quad 187$

Varia 187

No. 4

Original Paper

Zypen, E. van der and Fankhauser, F.: The Ultrastructural Features of Laser Trabeculo-puncture and Cyclodialysis. Problems Related to Successful Treatment of Chronic Simple Glaucoma (with 1 Colour Plate) . . 189

Gramer, E.; Pröll, M. und Krieglstein, G. K.:Die Perimetrie des blinden Flecks. EinVergleich zwischen kinetischer und com-putergesteuerter statischer Perimetrie 201

Gencik, A.; Kádasi, L.; Genciková, A., andGerinec, A.: Notes on the Genetics of Congenital Glaucoma 209

Sakimoto, G.; Une, H., and Ohba, N.: Effectsof Topically Applied Bupranolol on theIntraocular Pressure. Effects on the Untreated Eye 214

Starzycka, M.; Kowalska, A., and Kçdzíora, M.:Some Inorganic Constituents of the Sub-retinal Fluid 220 
Dufier, J. L.; Briard, M. L.; Bonaiti, C; Frezal, J., and Saraux, H.: Inheritance in the Etiology of Convergent Squint 225

Schmidt, B. und Guckes, C: Die meridionaleAmblyopie des Menschen. Ein einfacherklinischer Test 235

Clinicopathologic Case Reports

Sautter, H.: Bilateral Choroidal Metastasis ina Case of Alveolar Carcinoma (SalivaryGland Carcinoma) 243

Book Review 248

No. 5

Original Paper

Stellpflug, H.; Busse, H.; Niedermeier, M.undDittrich, H.: Augenveränderungen wäh-rend extrakorporaler Zirkulation 249

Chihara, E.; Nishi, R.; Asayama, K., and Tsu-kahara, I.: Treatment of Mooren's Ulcerby

Conjunctiva] Excision 258

Baikoff,G.; Colin, J.; Charleux,J. et Sourdille, Ph.: La souffrance endothéliale provoquéepar un cristallin artificiel 265

Kapoor, S. and Dasgupta, J.: ChromosomalAnomaly in a Female Patient with

AnteriorLenticonus 271

Okinami, S. and Tsukahara, I.: Acute SevereUveitis with Retinal Vasculitis and

RetinalDetachment (with 1 Colour Plate) 276

Nissen, S. H.: Acetazolamide in the Treatmentof Haemorrhagic Glaucoma 286

Küchle, H. J. und Richard, G.: Zur Therapiearterieller Gefässverschlüsse von Netzhautund Sehnerv 291

Haman, K.-U: Pseudointernukleäre Ophthal-moplegie bei einem Fall von Plasmozytomdes

Clivus 297

Clinicopathological Case Reports

Giovannini, A. and Consolani, A.: Contraceptive-Induced Unilateral Retinopathy . . . 302

Book Reviews $\square$ Buchbesprechungen · Livres

nouveaux $\quad 306$

No. 6

Original Paper

Farkas, L. G. and Cheung, G.: Orbital Measurements in the Presence of Epicanthi inHealthy North American Caucasians 309

De Molfetta, V.; Brambilla, M.; De Casa, N.; Arpa, P., and Riva, M.: Residual Corneal

Astigmatism after Perforating Keratoplasty 316

Contents

$\mathrm{V}$

Sayegh, F.: Obstruction of the Central RetinalArtery. Comparison of the Ophthalmodynamometry Measurements in Relation tothe Time 322

Rochels, R. und Neuhann, Th.: Ergebnisse der B-Bild-Echographie bei Drusen der Papille 330

Piper, H. F. und Feindt, K.: Über willkürlich auslösbare abnorme Augenbewegungen . .. 336

Clinicopathologic Case Reports

Jensen, O. A.: DNA 'Lakes' in a Malignant

Choroidal Melanoma. Clinico-pathological

Case Report 348 
Domarus, D. v.; Rieger, H. und Naumann, G. O. H.: «Rezidivierende Iritis» infolge von persistierendem hyperplastischem primärem Glaskörper mit Pseudophakia lipomatosa 354 Book Reviews $\quad 361$

A. Author Index 363

Subject Index 365 